\title{
Hypoglycemic activity of two Brazilian Bauhinia species: Bauhinia forficata L. and Bauhinia monandra Kurz.
}

\author{
Fábio de Sousa Menezes ${ }^{1,2 *}$, Andréa Barreto Mattos Minto ${ }^{1}$, Halliny Siqueira Ruela ${ }^{3}$, Ricardo \\ Machado Kuster ${ }^{3}$,Helen Sheridan ${ }^{2}$, Neil Frankish ${ }^{2}$
}

${ }^{1}$ Departamento de Produtos Naturais e Alimentos, Faculdade de Farmácia, Centro de Ciências da Saúde, Cidade Universitária, 21941-590, Rio de Janeiro, RJ, Brazil,

${ }^{2}$ School of Pharmacy and Pharmaceutical Sciences, Trinity College Dublin, Universtity of Dublin, 23 Westland Row,

Dublin 2, Ireland,

${ }^{3}$ Núcleo de Pesquisas de Produtos Naturais, Centro de Ciências da Saúde, Bloco H, Cidade Universitária, 21941-590, Rio de Janeiro, RJ, Brazil

\begin{abstract}
RESUMO: "Atividade hipoglicemiante de duas espécies de Bauhinia brasileira: Bauhinia forficata L. and Bauhinia monandra Kurz.". Extratos aquosos das folhas de Bauhinia forficata L. e Bauhinia monandra Kurz (10\% p/v) foram testados em camundongos normoglicêmicos, objetivando averiguar a sua atividade hipoglicemiante. Ambos os extratos mostraram atividade hipoglicemiante na metodologia empregada. Ainda, foi possível isolar de B. forficata L. dois flavonóides, quercetina-3,7-O-dirhamnosido e kaempferol-3,7-O-dirhamnosido, sendo as estruturas estabelecidas por técnicas clássicas de RMN. Apenas o derivado da quercetina foi identificado no extrato aquoso de Bauhinia monandra por CLAE.
\end{abstract}

Unitermos: Bauhinia forficata, Bauhinia monandra, Leguminosae, atividade hipoglicemiante, flavonoides, CLAE.

\begin{abstract}
The hypoglycemic activity of aqueous extracts from Bauhinia forficata L. and Bauhinia monandra Kurz leaves $(10 \% \mathrm{w} / \mathrm{v})$ was evaluated in normoglycemic mice. Both extracts have shown hypoglycemic activity using this methodology. It was also possible to isolate two flavonoids from $B$. forficata L., 3,7-di- $O-\alpha$-rhamnopyranosylquercetin and 3,7-di$O$ - $\alpha$-rhamnopyranosylkaempferol (kaempferitrin), whose structures were elucidated by usual NMR techniques. Only the quercetin derivative was identified in $B$. monandra aqueous extract by HPLC.
\end{abstract}

Keywords: Bauhinia forficata, Bauhinia monandra, Leguminosae, hypoglycemic activity, flavonoids, HPLC.

\section{INTRODUCTION}

Plants belonging to the genus Bauhinia are known in Brazil as "Pata-de-vaca" or "Unha-de-boi". Their species belong to the Leguminosae family and encompass circa 300 plants cultivated in tropical areas worldwide (Miyake et al., 1986). Aqueous extracts from Bauhinia species leaves, stems and roots, mainly B. cheilantha, B. forficata, B. glabra, B. rufescens, B. splendens and $B$. ungulata, are widely used in Brazil and in other countries in the treatment of several diseases, specially infections, pain processes and diabetes (Achenbach et al., 1988; Ritter et al., 2002; Pereira et al., 2004; Macedo; Ferreira, 2004; Morais et al., 2005; Silva et al., 2006). Several Bauhinia species are utilized as folk medicines worldwide, including Africa, Asia, South America and Central America (Ayensu, 1978).
Phytochemical and pharmacological studies with species of this genus are ongoing and, consequently a wide range of compounds have been isolated and identified, including lactones, flavonoids, terpenoids, glicolipids, glucosyl steroids, steroids, tannins and quinines (Cechinel-Filho et al., 1996, Silva et al., 2000; Mendes et al., 2006). One early study, by Bhartiya and Gupta (1981), identified 3,4-dihydroxychalcone-4-O$\beta$-L-arabinopyranosyl- $O$ - $\beta$-D-galactopyranoside from $B$. purpurea seeds. Roots and stems of this plant are popularly used in the treatment of diarrhea in India. During the same period studies with the methanolic extract $(2 \mathrm{~g} / \mathrm{kg})$ of $B$. racemosa flowers in gastric ulcer model induced by acetylsalicylic acid in rats have shown that this extract significantly reduced the ulcer index (Akhtar et al., 1981). A glucosyl steroid has been isolated from $B$. candicans aerial parts and identified as sitosterol- 
3-O- $\alpha$-D-riburonofuranoside (Irribarren; Pomilio, 1985). Achenbach et al. (1988), in a phytochemical study of $B$. manca stems have isolated 3-O-galloylepicatequine as its main constituent. They also identified gallic acid, cinnamic acid, $\beta$-sitosterol and $\beta$-D-glucosyl-sitosterol in significant concentrations. Alkaloids were not detected.

All the extracts from $B$. splendens leaves, stems, barks and roots, except the hydroalcoholic extract from its roots, have shown significant analgesic effect $(10 \mathrm{mg} /$ $\mathrm{kg}$ ) in a pain model induced by acetic acid $0.6 \%$ in mice, being more efficient than salicylic acid and paracetamol. In the same study the chemical constituents from leaves, stems, barks and roots extracts were evaluated by thin layer and column chromatography. Identified compounds include ethyl gallate, rutin and quercetin (Cechinel-Filho et al., 1996).

In a more recent study, Taylor et al. (1996), on Bauhinia species used in folk medicine in Nepal, the methanolic extract from B. vahlii roots was found to be one of the most active in the treatment of virusinduced diseases with specific activity toward Herpes simplex. A later chemical study of the methanolic extract obtained from B. purpurea wood led to the isolation and identification of 6-butyl-3-hydroxyflavanone (Kuo et al., 1998). More recently the ethanolic extract from $B$. guianensis stem barks has shown a very good activity against Plasmodium vinckei $(50 \mathrm{mg} / \mathrm{kg}$ ) (Muñoz et al., 2000) in an evaluation of one hundred and fifty six different species belonging to different families indicated by "Chacabos" (native community of Amazon Region) for the treatment of several diseases such as digestive complaints, ulcer, diarrhea, malaria, etc. Yadava and Tripathi (2000) have isolated 5,6-dihydroxy-7-methoxyflavone-6-O- $\beta$-D-xilopyranoside from the chloroform fraction of the total ethanolic extract from $B$. purpurea barks. Extracts from the bark of $B$. guianensis stems have been shown to possess antinociceptive effects in the acetic acid writhing model in mice, as well as anti-inflammatory activity in the carrageenan, dextran and histamine paw edema model in rats (Silva; Cechinel-Filho, 2002; Falcão et al., 2005).

Based on the study of Cechinel-Filho et al. (1996) with B. splendens, Silva and Cechinel-Filho (2000) have studied B. forficata, used by the Brazilian Pharmacopoeia for the physical-chemical and botany parameters for the quality control of this species. The phytochemical study of this species showed the presence of a kaempferol-3,7-dirhamnoside (kaempferitrine, lespedin) in the methanolic extracts of leaves and $\beta$ sitosterol from the hexane fraction. A comparative study carried out with all the vegetative organs of this species (leaves, roots and barks) has proved that steroids and terpenes are present in all of them, being more concentrated in the leaves. Lespedin was detected only in B. forficata leaves and because of that, this compound can be considered the chemical marker of this species for quality control purposes, present in leaves and absent in other parts.

The documented use and potential of Bauhinia species to act as hypoglycemic agents have begun to receive much attention. Bauhinia divaricata, known in Mexico as "pezunã de vaca", has been studied regarding its hypoglycemic activity and its aqueous extract (obtained from leaves) showed a relatively significant hypoglycemic effect in normal mice (Gupta et al., 1980). It has been established that the aqueous extract from $B$. megalandra inhibits the glucose intestinal absorption (Gonzales-Mujica et al., 2003) in rats. However, the hypoglycemic activity of Bauhinia species has been most extensively researched in $B$. forficata, which is considered by the rural population in Brazil as the "true pata-de-vaca". B. forticata Link. had its hypoglycemic activity confirmed by Juliane (1929, 1931). This species leaves are currently used in Brazil, in the form of aqueous extract(Modesto-Filho, 1988; Barbosa-Filho et al., 2005). However, a later study by Coimbra-Teixeira et al. (1992) has shown that the alcoholic leaves extract do not make the glucose blood levels lower in diabetic rats induced by streptozotocin.

Due to conflicting scientific results and the fact that Bauhinia species are widely used in Brazil as hypoglycemic plants, without any control, using popular knowledge that correlates the color of the flowers with the suggested activity power, we have decided to investigate the hypoglycemic activity of the aqueous extract of two Bauhinia species used in the State of Rio de Janeiro, Brazil. The selected species are Bauhinia forficata L. and Bauhinia monandra Kurz. A second objective is to try and isolate one or more markers for these species that could be responsible, at least in part, for their activity in normoglycemic mice, and could find potential use for quality control purposes.

\section{MATERIAL AND METHODS}

\section{Plant material}

Bauhinia forficata L. and B. monandra Kurz were collected in different parts of Rio de Janeiro State and prepared for the study. These species were identified by Professor Ângela Studart da Fonseca Vaz from the Botanical Garden of Rio de Janeiro, specialist in Leguminosae family. Two voucher samples are deposited in the Botanical Garden of Rio de Janeiro Herbarium under the numbers 3456 and 3765 respectively.

\section{Extracts preparation and animals}

The aqueous extracts from the two mentioned species were prepared in the concentration of $10 \%(\mathrm{w} / \mathrm{v})$ using dried leaves $(2 \mathrm{~g})$. Further their preparation they were administered to Swiss mice (male, medium weight between 20 and $25 \mathrm{~g}$ ). Animals were maintained in room temperature with free access to water and food. 
Animal care and research protocols were in accordance with the principles and guidelines adopted by the Brazilian College of Animal Experimentation (COBEA) and approved by the Biomedical Science Institute/UFRJ-Ethical Committee for animal research.

\section{Animal blood collection and glucose level determination}

All blood samples were collected by orbital puncture, obtained from the ophthalmic plexus, in animals under anesthesia with ethylic ether. Blood was collected in heparin capillaries for micro hematocrit with capacity of $70 \mathrm{~mL}$ and centrifuged at $11000 \mathrm{rpm}$ for 5 minutes in order to separate plasma. After its separation, an aliquot of $20 \mathrm{~mL}$ was collected and glucose-oxidase (color reagent) was added in a glass tube, named sample tube (S). Standard solution $(20 \mathrm{~mL})+2 \mathrm{~mL}$ of a glucoseoxidase solution was used as positive control (C) and 2 $\mathrm{mL}$ of glucose-oxidase solution was used as blank (B). The plasmatic glycemia was achieved by the glucose/ oxidase methodology. In this method, hydrogen peroxide formed by the catalytic action of the enzyme glucoseoxidase in D-glucose was measured by the oxidation of $o$-dianisidine in the presence of peroxidase.

\section{Determination of glycemia in normoglycemic animals}

Mice $(\mathrm{n}=8)$ were used to verify the hypoglycemic activity from the two studied species of Bauhinia which the aqueous extract was administered by oral route to male mice in a concentration of $10 \%(\mathrm{w} / \mathrm{v})$.

Animals were left fasting receiving water since 12 hours before the onset and during all the experiment. The basal glycemia (time $=$ zero) was determined and further each group received its appropriate treatment. Each control group received distillated water $0.1 \mathrm{~mL} / 10 \mathrm{~g}$ of weight, p.o. and each treated group received aqueous extract $(10 \% \mathrm{w} / \mathrm{v})$ of one of the two tested Bauhinia species $0.1 \mathrm{~mL} / 10 \mathrm{~g}$ of weight, p.o.

The glycemia of each group was observed in 2 , 4,6 and 8 hours after the onset of the experiment with or without the administration of aqueous extract.

\section{Separation, isolation and identification of the suggestive active compounds}

The high performance liquid chromatography was made in a Shimadzu CBM $10^{\mathrm{A}}$ apparatus equipped with a LC-10AD pump and SPD-M10A DAD detector, manual injection valve Rheodyne with $20 \mathrm{~mL}$ of capacity, column Lichrosorb (Merk N. 738342) RP-18 (250 x 4 $\mathrm{mm}$, internal diameter $10 \mathrm{~mm}$ ). The monitoring was in fix wavelength $(254 \mathrm{~nm})$. The mobile phase was formed by $1 \%$ phosphoric acid solution in water (Solvent A) and $1 \%$ phosphoric acid solution in methanol Solvent B) flowing at $1 \mathrm{~mL} / \mathrm{mim}$. The gradient beginning with
$30 \%$ of $\mathrm{B}$ growing to $40 \%$ of $\mathrm{B}$ in ten minutes. This composition remaining isocratic up to 20 minutes when another gradient was started going to $100 \%$ of B in 60 minutes, maximum time of the chromatographic process. Using this methodology, it could be possible to isolate from Bauhinia forficata aqueous extract, two glucosyl flavonoids: $\quad 3,7$-di- $O-\alpha$-rhamnopyranosylkaempferol, kaempferitrin, $(\mathrm{RT}=24$ minutes) and 3,7-di- $O-\alpha$ rhamnopyranosyl quercetin ( $\mathrm{RT}=32$ minutes).

These compounds were identified by ${ }^{1} \mathrm{H}$ NMR $(200 \mathrm{MHz})$ and ${ }^{13} \mathrm{C}$ NMR $(50 \mathrm{MHz})$ spectra registered in a Varian Star-200 apparatus, with deuterated solvents and TMS as internal standard. The $400 \mathrm{MHz}{ }^{1} \mathrm{H}$ NMR was registered in a Bruker DRX apparatus using the same conditions. After elucidated each structure, data were compared with literature previously published one and by his way, it was possible to confirm the identity of each compound. The analysis of $B$. monandra aqueous extract and co-injection with the isolated molecules from B. forficata made possible to visualise or not the same compounds.

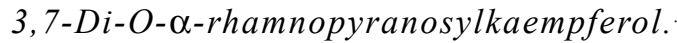

${ }^{1} \mathrm{H}$ NMR (200 MHz, DMSO-d6, TMS): $\delta$ (ppm) 0.81.1 (methyl groups of rhamnose, $2 d$ ), 3.1-4.0 (signals concerning the $\mathrm{H}$ of the sugar moiety of this molecule) $5.3(\mathrm{sl}$, anomeric $\mathrm{H}$ from rhamnose in the position 3), $5.55 \mathrm{sl}, \mathrm{H}$ anomeric $\mathrm{H}$ from rhamnose in the position 7), 6.45 (sl, H-8), $6.75(s l, \mathrm{H}-6), 6.9(d, J 8.43 \mathrm{~Hz}, 2 \mathrm{H}$, H-3' and $\mathrm{H}-5$ '), $7.75\left(d, J 8.42 \mathrm{~Hz}, 2 \mathrm{H}, \mathrm{H}-2\right.$ ' and $\mathrm{H}-6$ '). ${ }^{1} \mathrm{H}$ NMR (200 MHz, CD 30 OD, TMS): $\delta$ (ppm) 0.9-1.3 (methyl groups of rhamnose, $2 d$ ), 3.3-3.9 (signals concerning the $\mathrm{H}$ of the sugar moiety of this molecule), $5.4(d, J 1.6 \mathrm{~Hz}$, $\mathrm{H}$ anomeric $\mathrm{H}$ from rhamnose in the position 3), 5.6 (d, $J 1.16, \mathrm{H}$ anomeric $\mathrm{H}$ from rhamnose in the position 7), $6.44(d, J 2.1 \mathrm{~Hz}, \mathrm{H}-8), 6.7(d, J 2.0 \mathrm{~Hz}, \mathrm{H}-6), 6.94(d$, $J 8.80 \mathrm{~Hz}, 2 \mathrm{H}, \mathrm{H}-3$ ' and $\mathrm{H}-5$ ') $7.78(d, J 8.80 \mathrm{~Hz}, 2 \mathrm{H}$, $\mathrm{H}-2$ ' and $\mathrm{H}-6$ '). ${ }^{13} \mathrm{C}$ NMR (50 MHz, $\mathrm{CD}_{3} \mathrm{OD}$, TMS): $\delta$ (ppm) 17.7 (C-1); 18.1 (C-6-Rha); 71.2 (C-5'-Rha); 71.6 (C-5-Rha); 71.8 (C-2-Rha); 72.1 (C-3-Rha, C-2'-Rha, C-3'-Rha); 73.1 (C-4'-Rha); 73.5 (C-4-Rha); 95.5 (C-8); 99.8 (C-6); 100.5 (C-1'-Rha); 103.5 (C-1-Rha); 107.5 (C8a); 116.6 (C-3'); 122.3 (C-1'); 131.9 (C-2'); 136.4 (C3); 157.9 (C-4a); 159.7 (C-2); 161.7 (C-4'); 162.9 (C-5); 163.5 (C-7); 179.7 (C-4).

3,7-Di-O- $\alpha$-rhamnopyranosylquercetin. $\quad{ }^{1} \mathrm{H}$

NMR (400 MHz, CD 3 OD, TMS): $\delta$ (ppm) 0.95-1.25 (methyl groups of rhamnose, 2 d), 3.34-4.25 (signals concerning the $\mathrm{H}$ of the sugar moiety of this molecule), $5.37(d, J 1.37 \mathrm{~Hz}, \mathrm{H}$ anomeric $\mathrm{H}$ from rhamnose in the position 3), $5.56(\mathrm{sl}, \mathrm{H}$ anomeric $\mathrm{H}$ from rhamnose in the position 7), $6.47(d, J 2.05 \mathrm{~Hz}, \mathrm{H}-8), 6.73(d, J 2.05 \mathrm{~Hz}$, H-6), $6.92\left(d, J 8.21 \mathrm{~Hz}, \mathrm{H}-3^{\prime}\right), 7.33$ (dd, $J 2.05 \mathrm{~Hz}$ and $J$ $8,21 \mathrm{~Hz}, \mathrm{H}-2$ '), 7.37 (d, J $2.05 \mathrm{~Hz}, \mathrm{H}-6$ ').

\section{Statistical evaluation}

Data related to the animals glycemia were 
analyzed by an experimental design completely casual, applying variance analysis (ANOVA) in order to verify significant differences between the groups, with $5 \%$ of significance level $(\mathrm{p}<0.05)$. To compare control and experimental groups, t-Student test was applied. Nonpared t-Student test was applied to compare the glycemia average in each measured time. The results were expressed as an arithmetic average of glycemia in each measured time, with standard deviation. Each aqueous extract was evaluated in triplicate.

\section{RESULTS AND DISCUSSION}

Evaluation of the chromatograms of the aqueous extract of Bauhinia forficata and Bauhinia monandra by UV led to the visualization of signals which we believed to be glucosyl flavonoids (or flavonoid glycosides). In the case of Bauhinia forficata it was possible to isolate and identify two flavonoids with the following retention times: 3,7-di- $O$ - $\alpha$-rhamnopyranosylkaempferol, kaempferitrin, (24 minutes) and 3,7-di- $O$ - $\alpha$-rhamnopyranosylquercetin (32 minutes) (Figure 1). These compounds structures were established by NMR techniques. 3,7-di- $O-\alpha-$ rhamnopyranosylquercetin was also identified in the aqueous extract of Bauhinia monandra by comparison of both UV and retention data and by co-injection using HPLC. Table 1 shows the relative amount of both flavonoids in the two extracts. The quantitative relation between kaempferitrin and 3,7-di-O- $\alpha$-rhamnopyranosylquercetin observed in B. forficata aqueous extract used in this work is in accordance with those showed to another sample of $B$. forficata aqueous extract from Itajaí (South part of Brazil), which was also seen when they evaluated $B$. forficata fluid extract (Pinheiro et al., 2006). Flavonoids were also identified in the aqueous extract of $B$. monandra, although their structures have not been elucidated (Argolo et al., 2004).

The hypoglycemic activity was established for both species using the described methodology as it can be seen in Graphic 1. The results found in this work match some results previously published, at least for B. forficata (Jorge et al., 2004). In the same study, the isolated molecule (kampferitrin) was also evaluated on ${ }^{14} \mathrm{C}$-glucose uptake in rat soleus muscle and has shown insulinomimetic effects. The insulin-like effects of $B$. forficata aqueous extract were also evaluated in mice after scorpion envenoming. Although no insulinomimetic effect has been shown, this extract was able to enhance the venom lethality (Vasconcelos et al., 2004).

Based on these evidences, the hypoglycemic activity shown in this paper can be related to the presence of glucosyl flavonoids which have different qualitative and quantitative profiles in both extracts. Both species had a very pronounced effect in the in vitro method used to establish activity, showing them to be very promising hypoglycemic agents. It is interesting to note that no relationship was observed between the color of the flowers and the strength of the hypoglycemic activity. Also, hypoglycemic activity for other Bauhinia species has been shown using different methodologies (Fuentes et al., 2004; Almeida et al., 2006; Fuentes; Alarcón, 2006).

Further research is needed to permit us to

Table 1. Presence of 3,7-O-dirhamnosyl-kaempferol and 3,7-O-dirhamnosyl-quercetin in the studied Bauhinia aqueous extracts.

\begin{tabular}{lcc}
\hline Species & 3,7-O-Dirhamnosyl-kaempferol & $3,7-O$-Dirhamnosyl-quercetin \\
\hline B. forficata & ++++ & ++ \\
B. monandra & - & ++++ \\
\hline
\end{tabular}<smiles></smiles>

3,7-Di- $O$ - $\alpha$-rhamnopyranosylquercetin<smiles></smiles>

3,7-Di-O- $\alpha$-rhamnopyranosylkaempferol

Figure 1. Structure of the two isolated glucosyl flavonoids from the aqueous extract of $B$. forficata.

\begin{tabular}{r|c} 
& \\
\hline Rev. Bras. Farmacogn. & 11 \\
Braz J. Pharmacogn. & 11 \\
17(1): Jan./Mar. 2007 &
\end{tabular}




\section{Bauhinia forficata}
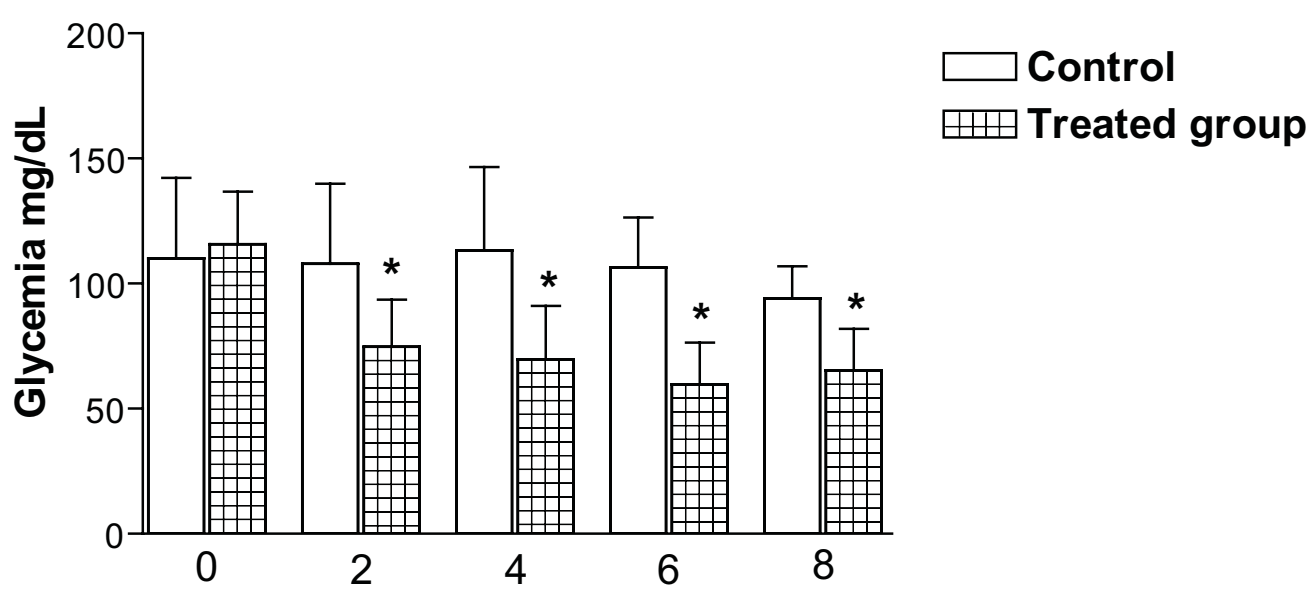

Time (h)

\section{Bauhinia monandra}

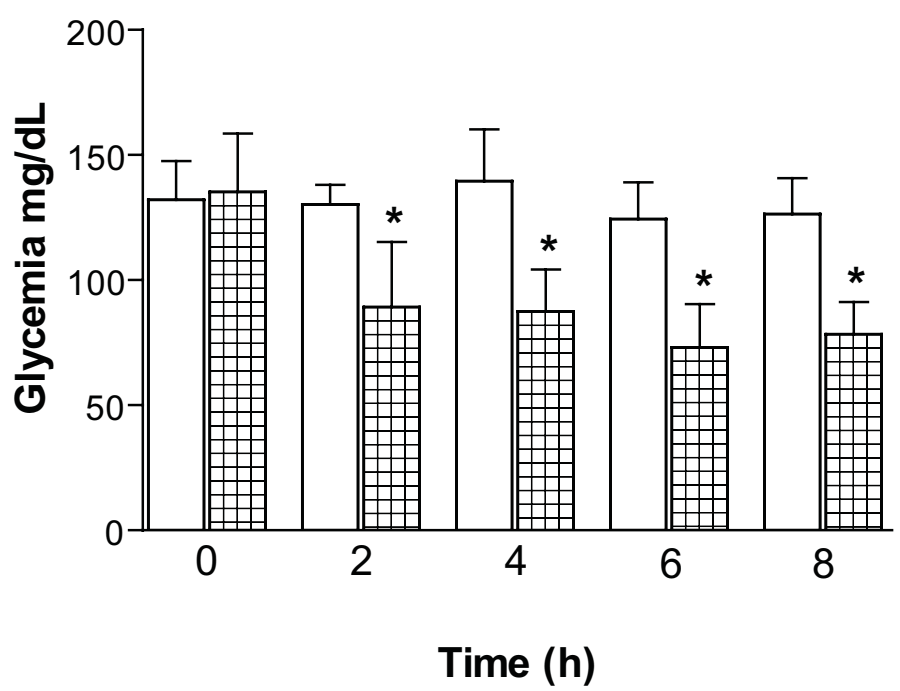

Graphic 1. Hypoglycemic activity for the aqueous extracts of B. forficata and B. monandra $(10 \%$ $\mathrm{w} / \mathrm{v}$ ) in $2,4,6$ and 8 hours. ${ }^{*} \mathrm{p} \leq 0.005$.

completely understand the way the aqueous extracts make the glucose blood level lower. It is now our intention to test the pure isolated molecules. Further studies also include the evaluation of these extracts and the extracts belonging to other Brazilian Bauhinia species, as well as their isolated compounds in beta-cell line culture (Asfari et al., 1992), to evaluate the efficacy of each extract and isolated compound in the elicitating the insulin production and release.

\section{REFERENCES}

Achenbach H, Stocker M, Constela MA 1988. Flavonoid and other constituents of Bauhinia manca. Phytochemistry 27: 1835-1841.


Akhtar MS, Athar MA, Yaqub M 1981. Effect of Mormodica charantia on blood glucose level of normal and alloxan-diabetic rabbits. Planta Med 42: 205-212.

Almeida ER, Guedes MC, Albuquerque JFC, Xavier H 2006. Hypoglycemic effect of Bauhinia cheilandra in rats. Fitoterapia 77: 276-278.

Argolo ACC, Sant'Ana AEG, Pletsch M, Coelho LCBB 2004. Antioxidant activity of leaf extracts from Bauhinia monandra. Bioresouce Technol 95: 229-233.

Asfari M, Janjic D, Meda P, Li G, Halban P, Wollheim C 1992.Establishment of 2-mercaptoethanoldependent differentiated insulin-secreting cell lines. Endoclinology 130: 167-178.

Ayensu ES 1978. The Medicinal and Poisonous Plants of Southern and Eastern Africa. Algonac: Reference Publications.

Barbosa-Filho JM, Vasconcelos THC, Alencar AA, Batista LM, Oliveira RAG, Guedes DN, Falcão HS, Moura MD, Diniz MFFM, Modesto-Filho J 2005. Plants and their active constituents from South, Central, and North America with hypoglycemic activity. Rev Bras Farmacogn 15: 392-413.

Bhartiya HP, Gupta PC 1981. A chalcone glycoside from the seeds of Bauhinia purpurea. Phytochemistry 20: 2051-2051.

Cechinel Filho V, Breviglieri E, Filho AW, Santos ARS 1996. Estudo fitoquímico e avaliação preliminar da atividade analgésica de Bauhinia splendens. Rev Bras Farm 76: 115-117.

Coimbra-Teixeira C, Danni FD, Blotta RM, Mussnich DG, Pereira da Costa P, Ranquetat GG 1992. Plants employed in the treatment of diabetes mellitus: results of an ethnopharmacological survey in Porto Alegre, Brazil. Fitoterapia 63: 320-323.

Falcão HS, Lima IO, Santos VL, Dantas HF, Diniz MFFM, Barbosa-Filho JM, Batista LM 2005. Review of the plants with anti-inflammatory activity studied in Brazil. Rev Bras Farmacogn 15: 381-391.

Fuentes O, Arancibia-Avila P, Alarcón J 2004. Hypoglycemic activity of Bauhinia candicans in diabetic induced rabbits. Fitoterapia 75: 527-532.

Fuentes O, Alarcón J 2006. Bauhinia candicans stimulation of glucose uptake in isolated gastric glands of normal and diabetic rabbits. Fitoterapia 77: 271-275.

Gonzalez-Mujica F, Motta AN, Marquez AH, Capote-Zulueta J 2003. Effects of Bauhinia megalandra aqueous leaf extract on intestinal glucose absorption and uptake by enterocyte brush border membrane vesicles. Fitoterapia 74: 84-90.

Gupta AK, Vidyapati TJ, Chauhan JS 1980. Chemical examination of the stem of Bauhinia divaricata. Planta Med 38: 174-176.

Iribarren AM, Pomilio AB 1985. Sitosterol 3-O- $\beta$-Driburonofuranosídio from Bauhinia candicans. Phytochemistry 24: 360-361.

Jorge AP, Horst H, Sousa E, Pizzolatti MG, Silva FRMB 2004. Insulinomimetic effects of kaempferitrin on glycaemia and on ${ }^{14} \mathrm{C}$-glucose uptake in rat soleus muscle. ChemBiol Interact 149: 89-96.

Juliane C 1929. Ação hipoglicemiante da unha-de-vaca. Rev Med Pharm Chim Phys 2: 165-169.

Juliane C 1931. Ação hipoglicemiante da Bauhinia forficata Link. Novos estudos experimentais. Rev Sudam
Endocrin Immol Quimiot 14: 326-334.

Kuo Y, Yeh M, Huang S 1998. A novel 6-butyl-3hydroxyflavanone from heartwood of Bauhinia purpurea. Phytochemistry 49: 2529-2530.

Macedo M, Ferreira AR 2004. Plantas hipoglicemiantes utilizadas por comunidades tradicionais na Bacia do Alto Paraguai e Vale do Guaporé, Mato Grosso-Brasil. Rev Bras Farmacogn 14(Supl. 1): 45-47.

Mendes BG, Machado MJ, Falkenberg M 2006. Triagem de glicolipídios em plantas medicinais. Rev Bras Farmacogn 16: 568-575.

Miyake ET, Akisue G, Akisue MK 1986. Pharmacognostic characterization of Pata-de-Vaca (Bauhinia forficata). Rev Bras Farmacogn 1: 56-58.

Modesto-Filho J 1988. Avaliação pré-clínica e clínica da atividade hipoglicemiante de Bauhinia forficata L. (pata-de-vaca). X Simpósio de Plantas Medicinais do Brasil. São Paulo, Brasil.

Morais SM, Dantas JDP, Silva ARA, Magalhães EF 2005. Plantas medicinais usadas pelos índios Tapebas do Ceará. Rev Bras Farmacogn 15: 169-177.

Muñoz V, Sauvain M, Bourdy G, Callapa J, Bergeron S, Rojas I, Bravo JA, Balderrama L, Ortiz B, Gimenez A, Deharo E 2000. A search for natural bioactive compounds in Bolívia through a multidisciplinary approach Part I. Evaluation of the antimalarial activity of plants used by the Chacobo Indians. J Ethnopharmacol 69: 127137.

Pereira RC, Oliveira MTR, Lemos GCS 2004. Plantas utilizadas como medicinais no município de Campos de Goytacazes - RJ. Rev Bras Farmacogn 14 (Supl. 1): $37-40$.

Pinheiro TSDB, Johansson LAP, Pizzolatti MG, Biavatti MW 2006. Comparative assessment of kaempferitrin from medicinal extracts of Bauhinia forficata Link. J Pharm Biomed Anal 41: 431-436.

Ritter MR, Sobierajski GR, Schenkel EP, Menth LA. Plantas usadas como medicinais no município de Ipê, RS, Brasil. Rev Bras Farmacogn 12: 51-62.

Silva KL, Biavatti MW, Leite SN, Yunes RA, Monache F, Cechinel-Filho V 2000. Phytochemical and pharmacognostic investigation of Bauhinia forficata Link. Z Naturforsch C 55: 478-480.

Silva KL, Cechinel-Filho V 2002. Plantas do gênero Bauhinia: Composição química e potencial farmacológico. Quim Nova 25: 121-125.

Silva MIG, Gondim APS, Nunes IFS, Sousa FCF 2006. Utilização de fitoterápicos nas unidades básicas de atenção à saúde da família no município de Maracanaú (CE). Rev Bras Farmacogn 16: 455-462.

Taylor RSL, Hudson JB, Manandhar NP, Towers GHN 1996. Antiviral activities of medicinal plants of southern Nepal. J Ethnopharmacol 53: 97-104.

Vasconcelos F, Sampaio SV, Garófalo MAR, Guimarães LFL, Giglio JR, Arantes EC 2004. Insulin-like effects of Bauhinia forficata aqueous extract upon Tityus serrulatus scorpion envenoming. J Ethnopharmacol 95: 385-392.

Yadava RN, Tripathi P 2000. A novel flavone glycoside from the stem of Bauhinia purpurea. Fitoterapia 71: 88-90. 